JURNAL PANGAN DAN GIZI 9 (1): 65-73, April 2019

ISSN 2086-6429 (Online)

Tersedia online di http://jurnal.unimus.ac.id/index.php/JPDG

\title{
Pengaruh Penggunaan Sisik Ikan Bandeng Terhadap Kadar Kalsium, Daya Kembang dan Organoleptik Camilan Stick
}

\author{
The Effect of Using Chanos Fish Scales To Calcium Levels, Swell Strength and \\ Organoleptic of Stick Snack
}

\begin{abstract}
Chairunnisa Nur Aulia Fajari, Muh Yusuf, Nurrahman
Program Studi Teknologi Pangan Universitas Muhammadiyah Semarang, Fakultas Ilmu Keperawatan Dan Kesehatan, Universitas Muhammadiyah Semarang, Jl. Kedungmundu Raya No. 18 Kec. Tembalang, Kota Semarang

Korespondensi, email : nischeaulia13@gmail.com
\end{abstract}

\begin{abstract}
Stick is snack which favoured by society but lack of nutrition content, especially mineral calcium, then needed an other materials to completed it with the addition of Chanos fish scales fluor. The general purposed of this research was to determined the effect of used Chanos fish scales to calcium levels, swell strength and organoleptic of stick snack. The method of this research is experiments methods used completely randomized design (RAL) monofaktorial by a factor variation of addition 0\%, 1\%, 2\%, 3\%, 4\% and 5\%. Statistical analysis showed an influence from the addition of fish scales fluor to calcium levels and organoleptic that showed from $p$ value $<0,05$, but no influenced on the swell strength. The best treatment of this research are 3\% additional of fish scales with calcium levels $0,38 \%$, swell strength value 1,375\%, quality scale value 3,675 and hedonic value 2,83. The conclution of this research are more higher percentage additional of Chanos fish scales will increase calcium level and hedonic value but degraded the quality scale value.
\end{abstract}

Keywords: stick, fish scales and calcium

\section{PENDAHULUAN}

Indonesia adalah negara kepulauan yang memiliki potensi besar di bidang perikanan. Hal ini menimbulkan permasalahan yaitu belum tersedia unit pengolahan limbah perikanan.

Meningkatnya produksi ikan akan diiringi peningkatan limbah ikan berupa kulit dan sisik ikan. Limbah dari sektor perikanan selain dihasilkan oleh Tempat Pelelangan 
Ikan (TPI) juga dihasilkan oleh industriindustri kecil terutama dibidang pengasapan ikan, presto ikan, terasi dan ikan asin. Saat ini belum ada upaya untuk mengolah lebih lanjut limbah perikanan berupa kulit dan sisik ikan (Hartanti, 2010).

Bagian-bagian tubuh ikan selain daging ikan merupakan hasil samping (byproduct). Daging ikan yang bisa dikonsumsi (edible portion) berkisar antara 40-50\% sedangkan tulang, kepala dan sirip diambil asam lemak omega-3 dan gelatinnya atau dijadikan tepung tulang sebagai tambahan kalsium pada pakan ternak. Ikan juga menghasilkan berbagai limbah hasil samping proses produksi, berupa limbah cair dan padat. Limbah padat (kulit dan sisik) mengandung kalsium yang cukup tinggi (Trilaksani, 2004), sehingga berpotensi menjadi bahan fortifikan pada produk pangan, hal ini akan meningkatkan nilai jual (marketable) produk (Mulyani, 2012).
Ikan bandeng dikonsumsi seluruh golongan masyarakat. Namun konsumsi bandeng pada masyarakat pedesaan $(0,884$ $\mathrm{kg} / \mathrm{kapita} / \mathrm{tahun}$ ) lebih rendah daripada masyarakat perkotaan $\mathrm{kg} / \mathrm{kapita} / \mathrm{tahun}$ ). Hal ini dikarenakan ketersediaan bandeng di kota lebih memadai. Umumnya daerah produksi bandeng berada di pantai yang relatif dekat dengan daerah perkotaan. Semakin tinggi pendapatan semakin tinggi tingkat konsumsi masyarakat akan bandeng, dan semakin tinggi pula limbah hasil samping yang dihasilkan khususnya adalah limbah sisik ikan bandeng (Rusmiyati, 2014).

Informasi yang didapatkan mengenai kandungan sisik ikan bandeng belum ada. Maka pada penelitian ini akan menganalisa pula tentang kandungan proksimat dan kalsium sisik ikan bandeng. Camilan stick merupakan salah satu jenis makanan ringan yang digemari masyarakat. Untuk menambah daya tarik dari stick maka dibutuhkan tambahan bahan untuk meningkatkan nilai gizi sehingga 
memberikan manfaat lebih saat

mengkonsumsinya (Pratiwi, 2013).

Menurut Indrasari et al., (2002), penggunaan tepung tapioka dan tepung terigu sebagai bahan baku pembuatan stick belum memperkaya kandungan gizi dari camilan stick. Diperlukan sumber gizi lain untuk melengkapinya.

Penelitian ini bertujuan untuk meningkatkan nilai gizi camilan stick dengan sisik ikan bandeng yang mengandung kalsium cukup tinggi. Namun mudah didapat dan pemanfaatannya belum maksimal. Sisik ikan diduga dapat meningkatkan kadar kalsium. Di sisi lain harus diketahui pengaruhnya terhadap daya kembang dan organoleptik. Diharapkan menjadi salah satu alternatif camilan yang bergizi.

\section{BAHAN DAN METODE}

\section{Bahan}

Bahan yang digunakan dalam penelitian ini antara lain sisik ikan bandeng, tepung terigu, telur, dan berbagai bahan kimia untuk analisa kalsium
Pembuatan Tepung Sisik Ikan

(Mulyani, 2012)

Sisik ikan bandeng dicuci dengan air bersih untuk menghilangkan kotoran. Sisik bersih direndam dalam air yang dicampur sari belimbing wuluh dengan perbandingan 2:1 dengan $\mathrm{pH} \mathrm{4,47} \mathrm{selama} \mathrm{satu} \mathrm{jam.} \mathrm{Hal}$ ini diperlukan untuk menghilangkan bau amis. Langkah selanjutnya adalah mencuci kembali sisik ikan, meniriskan dan mengeringkan sisik ikan menggunakan cabinet dryer di suhu $\pm 60^{\circ} \mathrm{C}$ selama $\pm 4-6$ jam. Menggiling sisik ikan yang telah mengering hingga berubah menjadi butirbutir tepung. Langkah terakhir adalah mengayak tepung sisik ikan dengan ayakan 100 mesh sehingga didapatkan hasil tepung sisik ikan yang halus.

\section{Pembuatan Stick (Pratiwi, 2013)}

Bahan yang dibutuhkan yaitu tepung sisik ikan bandeng, tepung tapioka $65 \mathrm{~g}$ dan bahan tambahan lain yaitu garam $\pm 1 \mathrm{~g}$, telur $70 \mathrm{~g}$ dan margarin $25 \mathrm{~g}$. Dilanjutkan dengan tahap mencampur bahan menjadi adonan kemudian dibentuk tipis dengan 
menggunakan penggiling $\mathrm{mi}$ hingga

ketebalan $\pm 2 \mathrm{~mm}$. Adonan dipotong memanjang dengan ukuran $\pm 10 \mathrm{~cm}$ dan digoreng dengan deep frying pada suhu $\pm 150^{\circ} \mathrm{C}$ selama \pm 3 menit.

\section{Kadar Kalsium (Noviyanti, 2011)}

Metode spektrofotometer serapan atom (SSA) yaitu abu yang berasal dari pengabuan kering ditambahkan 5-6 ml HCL $6 \mathrm{~N}$ kemudian dipanaskan di atas hot plate. Ditambahkan $15 \mathrm{ml} \mathrm{HCl} 3 \mathrm{~N}$, dipanaskan hingga mulai mendidih. Didinginkan dan disaring. Filtrat ditambah $10 \mathrm{ml} \mathrm{HCl} 3 \mathrm{~N}$, dipanaskan hingga mendidih dan didinginkan. Cawan dibilas dengan aquades, pembilas disaring dan dimasukkan dalam labu takar. Kertas saring dibilas dan pembilas dimasukkan dalam labu takar kemudian ditambahkan 5 ml larutan lantanum klorida untuk setiap $100 \mathrm{ml}$ larutan dan didinginkan. Larutan diencerkan hingga tanda tera.

Menyiapkan blangko dengan menggunakan pereaksi yang sama. Alat dikalibrasi terlebih dahulu. AAS di-setting sesuai dengan instruksi. Dilanjutkan dengan mengukur larutan standar logam, blanko dan larutan sampel. Selama penetapan sampel, secara periodik nilai standar diperiksa agar tetap konstan, kemudian membuat kurva standar untuk masing-masing logam (nilai absorpsi/emisi dan konsentrasi kalsium dalam mg/ml).

\section{Pengujian Daya Kembang (Suparyono,} 2015)

Tepung terigu dimasukkan ke dalam gelas ukur dengan ukuran tertentu dan dicatat, kemudian dipindahkan ke atas kertas saring dan disisakan $\pm 1 \mathrm{~cm}$ dalam gelas ukur. Stick yang akan diukur dimasukkan ke dalam gelas ukur hingga menempel pada tepung dan sisa dari tepung terigu yang ada pada kertas saring dimasukkan ke dalam gelas ukur tanpa tersisa. Sebaiknya bagian atas stick tertutup oleh tepung terigu dan diukur volume tepung setelah stick dimasukkan kemudian volume tepung sesudah stick dimasukkan dikurangi dengan volume tepung sebelum 
stick dimasukkan untuk menghitung volume stick yang mentah dan matang. Pengukuran daya kembang dari stick dapat dihitung dengan cara volume stick matang dikurangi volume stick mentah.

Vstick mentah $=$ Vtepung + stick mentah volume tepung

Vstick matang $=$ Vtepung + stick matang volume tepung

$\%$ Daya kembang $=\frac{\text { Vstick matang }}{\text { Vstick mentah }}$ $\times 100 \%$

\section{Organoleptik (Lailiyana, 2012)}

Pengujian organoleptik dimulai dengan merencanakan dan memilih peralatan yang akan digunakan. Pengarahan panelis berisi penjelasan tentang kegunaan uji, cara pengisian formulir dan peran panelis terkait pengujian. Uji organoleptik yang dilakukan adalah uji skala mutu dan uji kesukaan panelis.

\section{Rancangan Penelitian}

$$
\text { Rancangan penelitian ini }
$$

menggunakan RAL (Rancangan Acak
Lengkap) faktor tunggal. Variabel independent adalah jumlah tepung sisik ikan yang ditambahkan dalam pembuatan stick $(0 \%, 1 \%, 2 \%, 3 \%, 4 \%$ dan $5 \%)$. Persen penambahan dari tepung komposit (tepung terigu dan tapioka). Variabel depedent adalah kadar kalsium, daya kembang dan organoleptik. Masing-masing percobaan dilakukan ulangan sebanyak 4 kali, sehingga diperoleh satuan (unit) percobaan sebanyak 24 unit percobaan.

\section{HASIL DAN PEMBAHASAN}

\section{Poksimat Sisik Ikan Bandeng}

Karakteristik kimia sisik ikan bandeng didapatkan melalui uji proksimat, yang terdiri dari uji kadar air, abu, protein, serat dan lemak. Sesuai dengan Nagai et al., (2004) bahwa kandungan sisik ikan secara umum adalah air $70 \%$, protein $27 \%$, lipid $1 \%$ dan abu $2 \%$. Hasil uji proksimat dari sisik ikan bandeng ditampilkan dalam Tabel 1. 
Tabel 1. Hasil proksimat sisik ikan

\begin{tabular}{cc}
\multicolumn{2}{c}{ bandeng } \\
\hline Parameter & Rerata \\
\hline Abu (\%) & 13,16 \\
Air (\%) & 32,48 \\
Lemak (\%) & 2,41 \\
Protein (\%) & 45,07 \\
\hline
\end{tabular}

\section{Kadar Kalsium}

Kalsium sisik ikan bandeng adalah sebesar 7,2\%. Menurut Yogaswari et. al., (2010) ikan gurami dengan berat tubuh 1,2 kg memiliki sisik dengan kadar kalsium sebanyak 7,32\%. Berat gurami $0,3 \mathrm{~kg}$ memiliki sisik dengan kadar kalsium sebesar $6,49 \%$ dan $3,1 \mathrm{~kg}$ berat ikan gurami memiliki sisik dengan kadar kalsium sebesar 5,98\%.

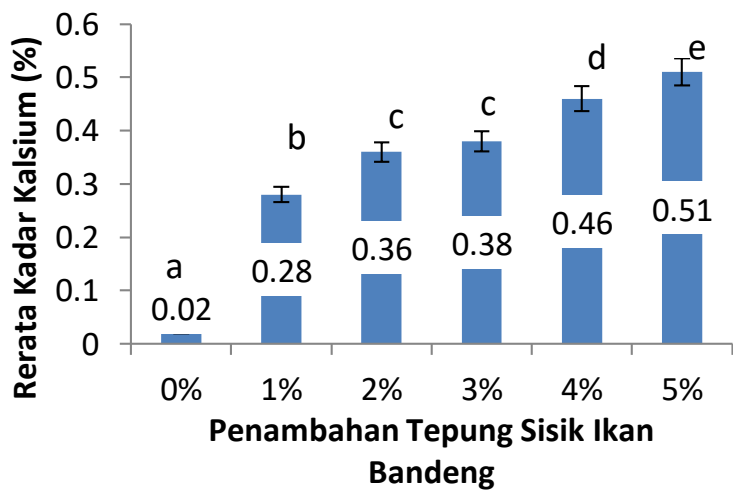

Uji Anova $p<0,05$ menunjukkan ada pengaruh penambahan tepung sisik ikan bandeng terhadap kadar kalsium. Hasil uji lanjut LSD menunjukkan ada perbedaan nyata pada setiap penambahan tepung sisik ikan bandeng. Setiap perlakuan memberi pengaruh nyata terhadap kontrol. Namun antara penambahan $2 \%$ dan $3 \%$ tidak menunjukkan perbedaan signifikan. Pada penambahan $4 \%$ dan 5\% menunjukkan ada perbedaan nyata. Semakin tinggi penambahan tepung sisik ikan bandeng, memberi kontribusi yang semakin tinggi terhadap kadar kalsium stick.

\section{Organoleptik}

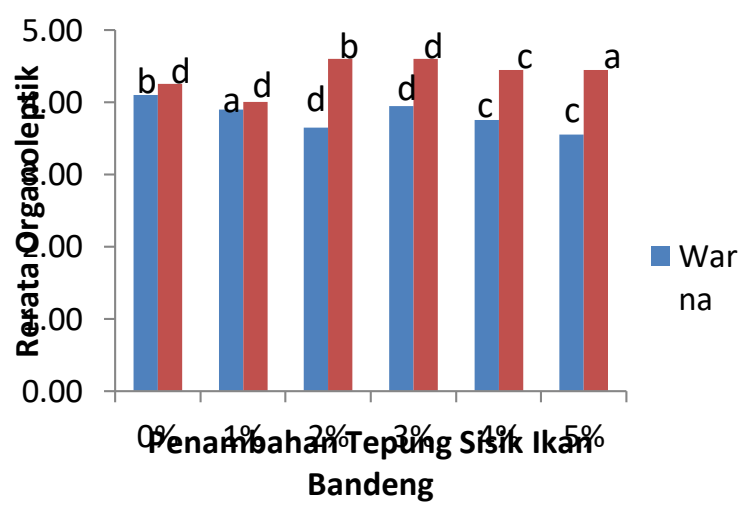

Gambar 2. Rerata Warna dan Aroma Stick Uji Wilcoxon menunjukkan ada perbedaan nilai rerata warna pada setiap penambahan tepung sisik ikan bandeng. Penambahan $2 \%$ dan $3 \%$ warna yang dihasilkan kuning keemasan dan pada penambahan 4-5\% warna stick akan menjadi pucat (krem), maka dapat 
disimpulkan bahwa dengan penambahan sisik ikan bandeng dalam jumlah tertentu (2-3\%) dapat meningkatkan warna stick.

Perlakuan penambahan tepung sisik ikan bandeng yang diberikan tidak berpengaruh terhadap aroma. Hal ini dikarenakan bahan yang digunakan dalam pembuatan stick seperti terigu, tapioka dan garam tidak mempengaruhi aroma dari stick.

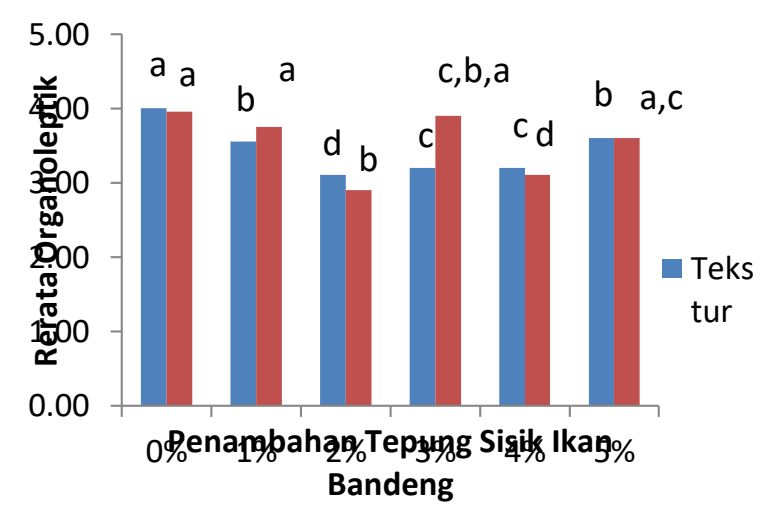

Gambar 3. Rerata Tekstur dan Rasa Stick

Jika dibandingkan dengan kontrol yang renyah cenderung agak keras dan tidak mudah hancur, maka tekstur stick dengan penambahan tepung sisik ikan 5\% adalah renyah namun lebih empuk dan lebih mudah hancur saat dikonsumsi. Semakin banyak penambahan sisik ikan akan mengakibatkan tekstur stick semakin empuk dan mudah hancur meski tetap renyah. Menurut Lailiyana (2012), konsistensi suatu bahan akan mempengaruhi tekstur yang ditimbulkan dari bahan tersebut. Uji Wilcoxon menunjukkan bahwa penambahan tepung sisik ikan bandeng berpengaruh nyata terhadap tekstur stick.

$$
\text { Penambahan sisik ikan }
$$
meningkatkan rasa gurih dari stick. Uji Wilcoxon menunjukkan ada perbedaan nyata pada penambahan tepung sisik ikan bandeng $2 \%, 3 \%$ dan $4 \%$. Rasa gurih disebabkan tepung sisik ikan bandeng memiliki kandungan potein yang tinggi. Bahan pembuat stick yang mengandung lemak seperti margarin dan minyak goreng berpengaruh memberi rasa gurih. Hal ini sesuai dengan Winarno, (1997) bahwa penyebab terjadinya rasa gurih dari suatu produk ditentukan oleh besarnya kandungan protein dan lemak di dalamnya. 


\section{Daya Kembang}

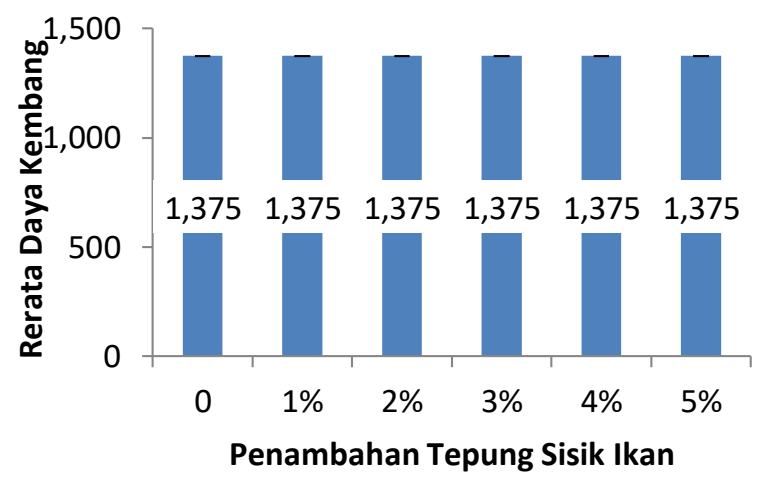

Gambar 4. Rerata Daya Kembang Stick

Hasil uji daya kembang menunjukkan bahwa tidak ada pengaruh penambahan tepung sisik ikan bandeng terhadap daya kembang camilan stick.

Penambahan 3\% tepung sisik ikan bandeng pada camilan stick merupakan perlakuan terbaik pada penelitian ini, meski nilai rerata dari setiap variabelnya masih lebih rendah dari kontrol. Namun kadar kalsium dari masing-masing stick meningkat, diharapkan dapat membantu menyumbang sebagian kebutuhan kalsium harian saat mengkonsumsi stick ini.

\section{KESIMPULAN}

Hasil analisa tepung sisik ikan bandeng adalah kalsium 7,2\%, air 32,48\%, abu $13,16 \%$, lemak $2,41 \%$ dan protein
$45,07 \%$. Penelitian yang telah dilakukan menunjukkan adanya perbedaan pada semua variabel kecuali pada daya kembang. Semakin besar penambahan tepung sisik ikan akan meningkatkan kadar kalsium dan kesukaan, namun menurunkan mutu organoleptik.

Perlakuan terbaik pada penelitian ini adalah penambahan tepung sisik ikan bandeng sebanyak 3\% dengan kadar kalsium $0,38 \%$, daya kembang 1,375\%, skala mutu 3,675 (paling mendekati kontrol), nilai kesukaan warna 4,6 (sangat suka), kesukaan aroma 3,95 (suka), kesukaan tekstur 3,20 (suka) dan kesukaan rasa 3,9 (suka)

\section{DAFTAR PUSTAKA}

Hartanti, I. Kurniasari, L. 2010. Semarang. "Kajian Produksi Kolagen dari Limbah Sisik Ikan Secara Ekstraksi Enzimatis". Jurusan Teknik Kimia Fakultas Teknik Universitas Wahid Hasyim Semarang, Semarang

Indrasari. 2002. Pengolahan Aneka Kue Stick dan Manfaatnya Bagi Kesehatan. Alfabeta. Bandung

Lailiyana. 2012. Depok. Tesis. Analisis Kandungan Zat Gizi dan Uji Hedonik Cookies Kaya Gizi pada Siswi SMPN 27 Pekanbaru Tahun 2012. Fakultas Kesehatan Masyarakat Program Studi Ilmu 
Kesehatan Masyarakat. Universitas Indonesia

Mulyani, Y. Farida. 2012. Balikpapan. "Pemanfaatan Limbah Sisik Ikan Kakap Merah Menjadi Keripik Sisik Ikan Kakap (Krisik Kakap)". Program Studi Tata Boga, Politeknik Negeri Balikpapan, Balikpapan

Noviyanti, Tri. 2011. Jakarta. "Skripsi Analisis Kalsium, Kadmium dan Timbal Pada Susu Sapi Secara Spektrofotometri Serapan Atom". Fakultas Matematika dan Ilmu Pengetahuan Alam. Program Studi Ekstensi Farmasi. Universitas Indonesia, Jakarta

Pratiwi, F. 2013. Semarang. Skripsi Pemanfaatan Tepung Daging Ikan layang untuk Pembuatan Stick Ikan. Jurusan Teknologi Jasa dan Produksi, Fakultas Teknik Universitas Negeri Semarang, Semarang

Rusmiyanti, S. 2014. Seri Perikanan Modern - Budidaya Bandeng Super: Langkah Jitu Menuju Kemapanan
Finansial. Pustaka Baru Press. Yogyakarta

Suparyono, B. Oktavia. 2015. "Subtitusi Tepung Kimpul (Xanthosoma sagittifolium) dan Tepung Terigu terhadap Sifat Fisiko Kimia dan Sensori Roti Manis". Fakultas Pertanian. Universitas Lampung, Lampung.

Trilaksani, W. 2004. "Diversifikasi dan Pengolahan Hasil Samping Produk Perikanan". Departemen Teknologi Hasil Perikanan. Fakultas Perikanan dan Ilmu Kelautan. Institut Pertanian Bogor

Winarno, F.G. 1997. Kimia, Pangan Dan Gizi. PT.Gramedia Pustaka Utama. Jakarta

Yogaswari, V. Nurjanah. Suwandi, R.. 2010. Bogor. "Karakteristik kimia dan fisik sisik ikan gurami (Osphronemus gouramy)". Fakultas Perikanan dan Ilmu Kelautan Institut Pertanian Bogor. AKUATIK-Jurnal Sumberdaya Perairan Vol. 4 No. 2 ISSN : 1978-1652 hal 7-9 